\title{
Suid-Afrikaanse aandelemarkontwikkeling: Die impak van globalisme en nasionalisme
}

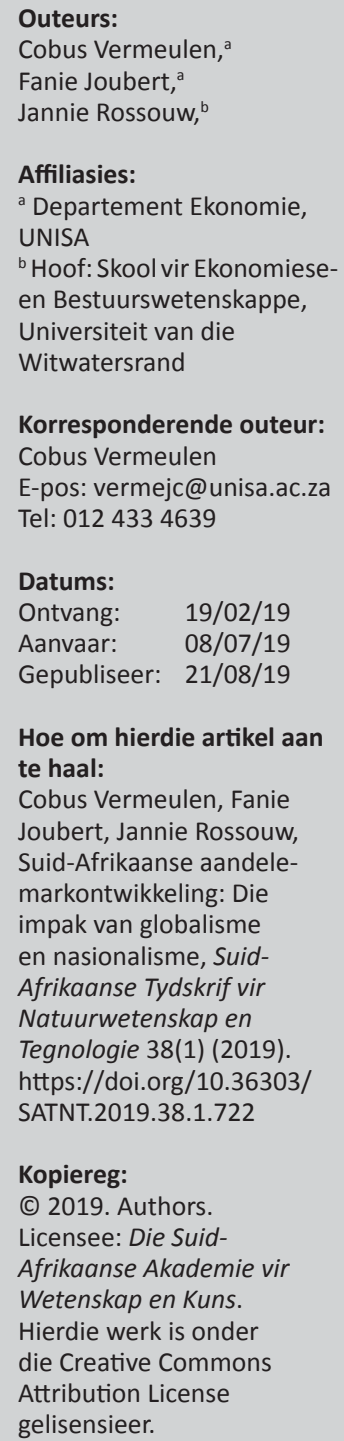

\begin{abstract}
Hierdie navorsing ondersoek die faktore wat die ontwikkeling van die Suid-Afrikaanse aandelemark (die Johannesburgse Aandelebeurs, JSE) aandryf, ten einde te bepaal of JSEontwikkeling oorwegend deur internasionale (globale) of plaaslike (nasionale) faktore aangedryf word. Vir hierdie doel word die ARDL grenstoets ("bounds test") gebruik as empiriese raamwerk waarbinne die rol van verskeie makro-ekonomiese veranderlikes, geklassifiseer as òf plaaslik òf internasionaal, in die ontwikkeling van die JSE - soos benader deur die markkapitalisasiekoers - ondersoek word. Die navorsingsbevinding is dat plaaslike ekonomiese groei, banksektorontwikkeling en rentekoerse, asook die wisselkoers en handelsoopheid die vernaamste langtermyndrywers van JSE-ontwikkeling is. Dus speel sowel plaaslike as internasionale faktore ' $n$ beduidende rol in die ontwikkeling van die JSE.
\end{abstract}

South African stock market development: The impact of globalism and nationalism: This study investigates the factors that drive the development of the South African stock market (the Johannesburg Stock Exchange, JSE), in order to determine whether the development of the JSE is driven mainly by international (global) or domestic (national) factors. To this end the ARDL bounds test is used as empirical framework within which the role of various macroeconomic variables, classified as either domestic or international, in the development of the JSE - approximated by the market capitalisation ratio - are evaluated. The study finds that the main long-term drivers of JSE development are domestic economic growth and interest rates, the development of the local banking sector, as well as the exchange rate and trade openness. Therefore, both domestic and international factors are significant in the development of the JSE.

\section{Inleiding}

Hierdie navorsing ondersoek aspekte wat aandelemarkontwikkeling in Suid-Afrika beïnvloed. Vir hierdie doel word die Johannesburgse Aandelebeurs (JSE) ontleed. Die JSE is in 1887 gedurende die goud-"stormloop" gestig, en is tans in terme van markkapitalisasie die 19de grootste aandelebeurs ter wêreld, en by verre die grootste in Afrika (WFE, 2018). Elektroniese verhandeling vind sedert die vroeë 1990s plaas en daar is tans ongeveer 400 maatskappye wat op die hoofbord verhandel. Die hoofbord bevat maatskappye met aansienlike markkapitalisasie, terwyl afgeleide instrumente ("derivatives") op die South African Futures Exchange (SAFEX), 'n filiaal van die JSE, verhandel. Die alternatiewe bord (AltX) vir klein- en middelslagmaatskappye (wat nie op hoofbord verhandel nie) is in 2003 van stapel gestuur. Die JSE is gedurende 2005 na 'n publieke maatskappy (JSE Beperk) omgeskakel ("demutualised"). Die JSE besit ook die Bond Exchange of South Africa (BESA) (JSE, 2017a).

Sedert sy stigting het die JSE meestal 'n monopolie op aandeelverhandeling in Suid-Afrika geniet. Die JSE se grootste mededinger gedurende die twintigste eeu was die Union Exchange, gestig in 1933, en gesluit in 1957 (SAHO, 2017). In 2016 het nuwe mededinging die mark vir aandeelverhandeling betree (Biznews, 2016). Dit sluit in die ZAR X, 4 Africa Exchange (4AX), asook A2X. Hul markaandeel is egter tans steeds weglaatbaar klein en daarom fokus hierdie navorsing slegs op die JSE.

Die JSE Top40 (J200) verteenwoordig die 40 grootste maatskappye op die beurs, soos bereken volgens volle markkapitalisasie. Met tye kan die indeks wel meer as 40 bydraende entiteite insluit, aangesien sommige maatskappye verskeie aandeelinstrumente uitreik (JSE, 2017b). Die JSE Top40 indeks is ' $n$ belangrike aanwyser aangesien dit ongeveer 80 persent van die totale JSE markkapitalisasie verteenwoordig (SA Shares, 2018). Gevolglik word die JSE Top40 dikwels as benadering ("proxy") vir die totale beurs of Alle Aandele Indeks (J203) gebruik. Figuur 1 dui aan dat aandelepryse, soos verteenwoordig deur die JSE Top40-indeks (die stippellyn), nóú verwant is aan totale markkapitalisasie (die soliede lyn). 


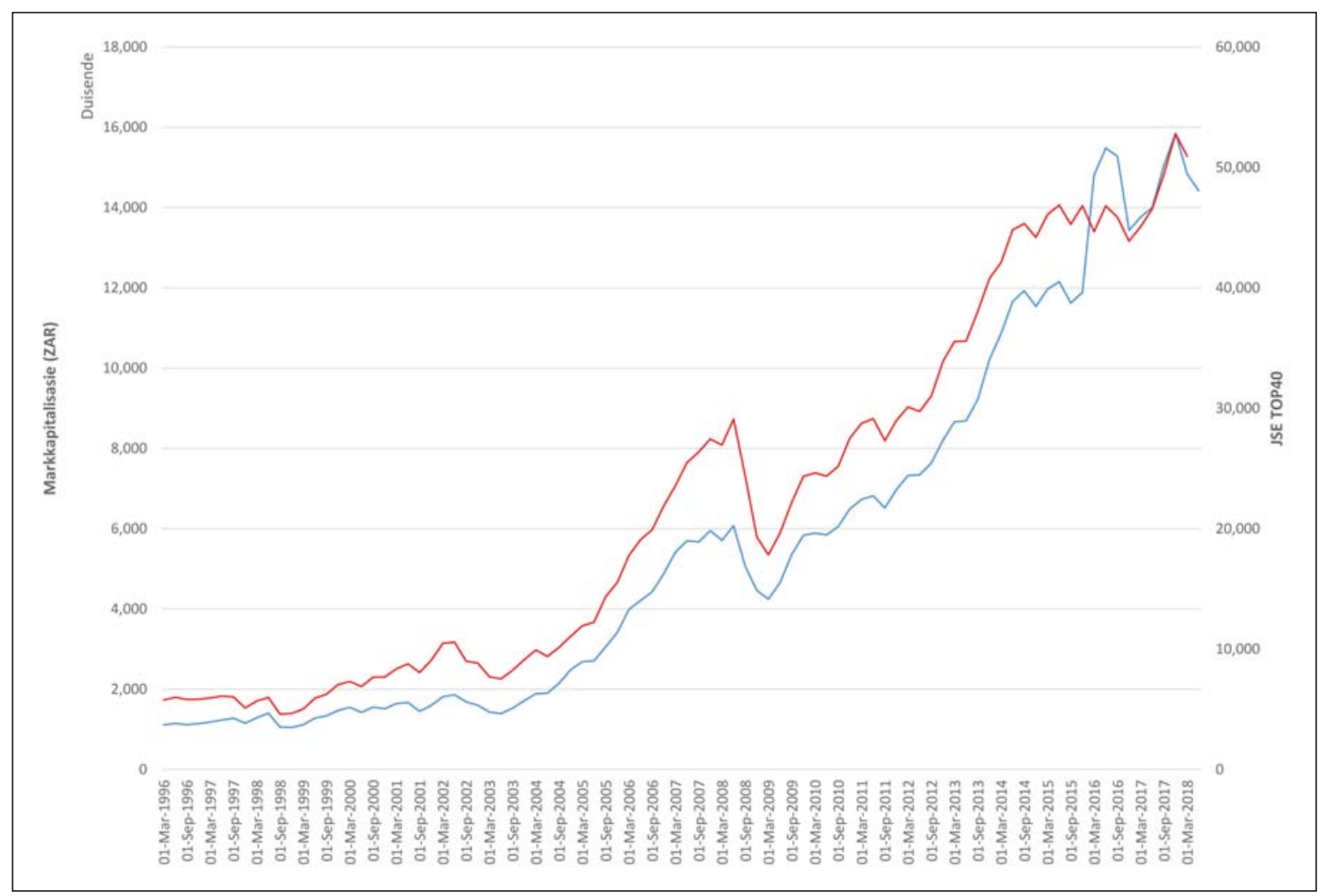

Figuur 1: Verwantskap tussen aandelepryse en markkapitalisasie, 1996 - 2018 Bron: SARB (2018) en eie berekeninge.

Daar bestaan omvattende literatuur oor die belangrike rol en positiewe impak van finansiële en kapitaalmarkontwikkeling op ekonomiese groei (sien bv. Levine, 2005 se deeglike oorsig), wat ook op die aandelemark van toepassing is. Volgens Garcia \& Liu (1999:35) is "finansiële ontwikkeling van kritiese belang vir ekonomiese groei". Die aandelemark is 'n sleutelspeler in die breër finansiële sektor en vervul ' $n$ belangrike funksie in die ekonomie, vernaam as tussenganger tussen finansiële markdeelnemers. Die aandelemark dra by tot "ekonomiese groei en ontwikkeling deur die mobilisasie van finansiële hulpronne te fasiliteer" (UNCTAD, 2017:2). Die teenwoordigheid van 'n gesonde en likiede aandelemark verlaag inligtings- en transaksiekoste, en lei tot die meer effektiewe aanwending en toedeling van kapitaal en skaars hulpbronne asook risiko-deling en -verskansing (Demirgüç-Kunt \& Levine, 1996).

'n Gesonde en groeiende aandelemark speel dus 'n belangrike rol in ekonomiese groei en ontwikkeling in die algemeen. Dit is daarom wenslik om die ontwikkeling van die aandelemark aan te moedig in belang van ekonomiese groei en ontwikkeling. Gevolglik is dit belangrik om die verwantskap tussen "ekonomiese ontwikkeling" en "aandelemarkontwikkeling" te analiseer. Hierdie analise fokus onder meer op faktore wat verantwoordelik mag wees vir die ontwikkeling van die aandelemark en die internasionale of plaaslike oorsprong van hierdie faktore. Daarvolgens neem hierdie artikel 'n ekonomiese invalshoek om moontlike aandrywers van die ontwikkeling van die JSE te ondersoek. Oorhoofs word daar onderskei tussen die impak van globale (internasionale) en nasionale (Suid-Afrikaanse) gebeure. Potensiële aandrywers van aandelemarkontwikkeling wat ondersoek word sluit, onder andere, ekonomiese groei, rente- en wisselkoerse, inflasie, internasionale kapitaalvloeie en handels-oopheid in. Die doel van hierdie navorsing is dus om te onderskei tussen plaaslike en internasionale faktore wat aandelemarkontwikkeling mag aandryf, om sodoende te bepaal watter faktore die ontwikkeling van die plaaslike beurs beïnvloed. Verder dra hierdie artikel tot die Suid-Afrikaanse empiriese literatuur by deur kwartaallikse data ${ }^{1}$ te gebruik om die beduidende aandrywers van die ontwikkeling van die JSE te bepaal.

Die res van hierdie artikel is soos volg gestruktureer: Afdeling 2 bespreek kortliks die literatuur oor aandelemarkontwikkeling en die belangrikste faktore wat dit mag beïnvloed. Die ekonometriese model en metodologie word in Afdeling 3 bespreek. Die resultate word in Afdeling 4 bespreek, en Afdeling 5 sluit af. 


\section{Literatuuroorsig: Ontwikkeling van 'n aandelemark}

Demirgüç-Kunt en Levine (1996) het in hul invloedryke artikel bepaal dat daar nie 'n "gemeenskaplike konsep of maatstaf van aandelemarkontwikkeling" (1996:291) bestaan nie. Aandelemarkontwikkeling is 'n "komplekse en veelkantige konsep" (1996:292), wat deur verskeie maatstawwe verteenwoordig kan word. Hulle het gevolglik verskillende moontlike anduiders van aandelemarkontwikkeling ondersoek, onder meer maatstawwe van die grootte, omset en aandelemarkkonsentrasie, wisselvalligheid, regulering en institusionele ontwikkeling. Hulle maak onder meer die gevolgtrekking dat 'n groter aandelemark, soos gemeet deur die markkapitalisasiekoers, effektief behoort te wees om kapitaal te mobiliseer en risiko's te diversifiseer (1996:294), wat daardeur ekonomiese ontwikkeling sou kon bevorder. Hierdie resultaat het vervolgens 'n groot gedeelte van die empiriese navorsing oor die volgende 20+ jaar onderskraag. Daar het inderdaad 'n breë konsensus ontstaan dat die markkapitalisasiekoers, tesame met die omsetkoers, die twee toonaangewende aanduiders van aandelemarkontwikkeling is. In kort word

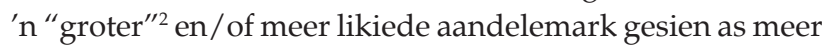
ontwikkeld; sodanige mark is dus in 'n beter posisie om ekonomiese groei en ontwikkeling te ondersteun. Vir die duur van hierdie navorsing gebruik ons dus die markkapitalisasiekoers as maatstaf van aandelemarkontwikkeling ${ }^{3}$.

In hul omvattende oorsig van die relevante literatuur kategoriseer Ho \& Iyke (2017) die faktore wat aandelemarkontwikkeling dryf volgens makro-ekonomiese en institusionele faktore. Makro-ekonomiese faktore kan ekonomiese groei en ontwikkeling, finansiële- en banksektorontwikkeling, inflasie, wisselkoerse, rentekoerse, kapitaalvloei, handels-oopheid, markrisiko (wisselvalligheid), en marklikiditeit insluit. Institusionele faktore sluit finansiële regulering, korporatiewebestuur ("corporate governance"), finansiële-markliberalisasie en aandelemarkintegrasie in. Daar bestaan ook 'n beduidende literatuur te make met mikro (portefeulje)-faktore, insluitend maatstawwe van opbrengs en variansie, dividende en verdienste, markgebaseerde aanduiders en verhoudings. Hierdie is egter 'n hoogs-tegnies en gespesialiseerde veld, en die fokus in hierdie navorsing val slegs op die eerste twee kategorieë.

Ho \& Iyke (2017) se makro/institusionele klassifikasie word hier as nasionale (plaaslike) en globale (internasionale) faktore hergroepeer:

\section{Nasionale faktore Ekonomiese groei}

Die grootte en die groeikoers van 'n ekonomie het 'n positiewe impak op die ontwikkeling van finansiële markte, wat die aandelemark insluit. Soos 'n ekonomie groei, neem die aantal deelnemers aan die finansiële markte toe, terwyl finansiële-markbedrywighede meer kosteeffektief raak (Greenwood \& Smith, 1997). Boyd \& Smith (1998) bewys voorts ook dat, soos 'n ekonomie ontwikkel, die relatiewe koste (prys) van kapitaal afneem. Goedkoper kapitale investeringsgeleenthede, bv. nuwe aandeleuitgifte, dra weer by tot 'n groeiende en meer aktiewe aandelemark, deur sowel die mark in staat te stel om meer en nuwe aandele te verhandel asook om die waarde van bestaande aandele te verhoog.

\section{Finansiële- en banksektorontwikkeling}

Aangesien die banksektor en aandelemark oorvleuelende funksies vervul, onder meer die voorsiening van markinligting, prysvastelling, korporatiewe bestuur en risikodeling (Ho \& Iyke, 2017), kan hulle gesien word as gedeeltelike substitute. Dus, die ontwikkeling van die een kan die ontwikkeling van die ander onderdruk indien daar ongesonde kompetisie tussen die twee is (Ho \& Iyke, 2017). Banksektorontwikkeling kan dus moontlik gepaard gaan met ' $n$ verlangsaming in die ontwikkeling van die aandelemark.

Daarteenoor kan die banksektor en aandelemark mekaar ook komplementeer deurdat beide finansiële funksies en -dienste verleen wat ekonomiese groei bevorder (Levine \& Zervos, 1998, Levine, 2005). Verder word besighede deur skuld of ekwiteit, of 'n kombinasie van die twee, gefinansier (Demirgüç-Kunt \& Levine, 1996:292). Skuldfinansiering (oorwegend lenings) word deur die banksektor voorsien, terwyl die aandelemark die voorsiener van ekwiteitsfinansiering is. Daarom kan die aandelemark ook banksektorontwikkeling aanmoedig, en omgekeerd, indien daar gesonde mededinging t.o.v. besigheidsfinansiering tussen die twee bronne bestaan. Goedkoper en meer effektiewe besigheidsfinansiering sal natuurlik ekonomiese groei en ontwikkeling bevorder, wat verder bydra tot aandelemarkontwikkeling.

\section{Inflasie}

Hoër inflasiekoerse gaan gepaard met "minder likiede en kleiner aandelemarkte" (Ho \& Iyke, 2017:146). Volgens Boyd et al. (2001) het inflasie die effek dat dit die reële opbrengs op monetêre en finansiële bates verlaag4. Dit verminder die beskikbaarheid van krediet (uitleners word nou terugbetaal in geld wat minder werd is in reële terme)

2 Let daarop dat die markkapitalisasiekoers bereken word as die verhouding van die totale waarde van genoteerde aandele teenoor die bruto binnelandse produk (BBP). Die absolute grootte van ' $n$ aandelemark word dus geweeg relatief tot die grootte van die ekonomie. Relatief tot die grootte van die ekonomie maak dit bv. die JSE vergelykbaar met die New York aandelebeurs (NYSE), wat ' $n$ sowat 35 keer groter beurs as die JSE is, maar ook in die Amerikaanse ekonomie, wat self sowat 55 keer groter as die SuidAfrikaanse ekonomie is, lê.

3 Sien ook Garcia \& Liu (1999), Boyd et al. (2001), Claessens et al. (2001), Yartey (2010), Ho (2018) en Ho \& Odhiambo (2018) wat 'n soortgelyke benadering volg.

4 Sien ook Mishkin (2013) vir ‘n algemene oorsig oor die negatiewe impak van inflasie op die breër ekonomie. 
en verhoog finansiële wrywings ("financial frictions"). Gevolglik word al hoe minder lenings toegestaan en die aanwending van finansiële bronne word minder doeltreffend, wat uiteindelik kapitaalinvestering en aandelemarkontwikkeling negatief raak.

\section{Plaaslike rentekoerse}

"Hoё" rentekoerse verhoog die koste van kapitaal, lenings en besigheidsfinansiering, wat dit minder aantreklik maak vir beleggers om in aandele te belê. Hoër rentekoerse gaan ook gepaard met 'n laer verdiskonteerde huidige waarde van toekomstige dividende, wat aandeelpryse negatief beïnvloed (Mok, 1993:123). Terselfdertyd stimuleer "lae" rentekoerse investering en belegging en ekonomiese bedrywigheid, wat weer aandeelpryse laat styg (Mok, 1993, Ho \& Iyke, 2017). Dit dui dus op 'n omgekeerde verwantskap tussen rentekoerse en aandeelpryse en aandelemarkontwikkeling.

Aan die ander kant sal die waarde van skuldinstrumente (bv. staats- of korporatiewe effekte) toeneem wanneer rentekoerse afneem (Mishkin, 2013). Dit kan veroorsaak dat beleggers hul fondse vanuit ekwiteit na substituutbeleggings skuif, wat die prys van aandele kan laat daal. Daarom kan die teoretiese impak van rentekoerse op die aandelemark positief of negatief wees, met die algehele impak afhanklik van plaaslike ekonomiese omstandighede en die voorkeure van markdeelnemers.

\section{Finansiële regulering en korporatiewe bestuur}

Geregtelike beskerming van beleggers speel 'n belangrike rol in aandelemarkontwikkeling (Ho \& Iyke, 2017). Deursigtigheid en goeie finansiële regulering verhoog die doeltreffendheid van aandelemarkte, en moedig beleggers aan om deel te neem aan aandelemarktransaksies. Beter beskerming van beleggers word ook geassosieer met meer effektiewe korporatiewe bestuur. Hierdie punt bevestig die belangrike rol van institusionele strukture.

\section{Marklikiditeit}

Likiditeit word gedefinieër as die "gemak en spoed waarteen agente finansiële instrumente kan koop en verkoop" (Garcia \& Liu, 1999:41). Garcia \& Liu (1999) en Yartey (2007) bevind dat hoër likiditeit gepaard gaan met hoër aandelemarkkapitalisasie. Hoe meer likied 'n beurs of aandelemark, hoe meer transaksies vind dus plaas, wat sal bydra tot die groei van die beurs (Garcia \& Liu, 1999).

\section{Globale faktore}

\section{Wisselkoerse}

Dornbusch \& Fischer (1980) se klassieke teorie postuleer dat'n sterker (swakker) geldeenheid gepaard gaan met laer (hoër) plaaslike aandeelpryse. Wisselkoersbewegings beïnvloed ' $n$ land se internasionale mededingendheid en dus sy betalingsbalansposisie. Dit beïnvloed weer 'n land se produksie en dus plaaslike maatskappye se kontantvloei en aandeelpryse. 'n Swakker wisselkoers verhoog 'n land se internasionale mededingendheid (dit is nou goedkoper vir die res van die wêreld om goedere en dienste vanuit hierdie land in te voer), wat plaaslike produksie en dus aandeelpryse positief behoort te raak.

Aan die ander kant redeneer Gavin (1989) dat die verhouding tussen die wisselkoers en aandeelpryse positief of negatief kan wees onder verskillende omstandighede. 'n Onverwagse positiewe vraagskok ("demand shock", vergelykbaar met 'n tydelike hoër ekonomiese groeitempo) veroorsaak hoër verwagtings van toekomstige winsgewendheid, wat lei tot hoër aandeelpryse. Aangesien so 'n skok gedryf kan word deur 'n swakker geldeenheid (bv. deur die waarde van uitvoer te verhoog), kan dit lei tot 'n negatiewe verwantskap tussen wisselkoerse en aandeelpryse, soortgelyk aan Dornbusch \& Fischer (1980) se bevindinge. Indien die vraagskok daarteenoor nie'n verassing is nie (m.a.w. daar is nie ' $n$ onverwagse verhoging in verwagte toekomstige winsgewendheid nie), kan 'n positiewe korrelasie tussen wisselkoerse en aandeelpryse gesien word (Gavin, 1989), wat sou beteken dat 'n sterker (swakker) geldeenheid gepaard gaan met hoër (laer) plaaslike aandeelpryse.

Die wisselkoers en wisselkoersbewegings beïnvloed ook die prys van dubbel-genoteerde aandele, m.a.w. aandele wat op beurse in lande met verskillende geldeenhede genoteer is.

\section{Kapitaalvloei}

Internasionale kapitaalvloei bestaan hoofsaaklik uit direkte buitelandse investering ("foreign direct investment", FDI) en portefeuljebeleggings, bv. buitelandse aankope van plaaslike finansiële instrumente soos aandele of effekte en bv. belegging in soewereine fondse of regte-uitgifte (Claessens \& Rhee, 1993). FDI kan gesien word as 'n plaasvervanger vir onderontwikkelde finansiële markte ${ }^{5}$, en plaaslike besighede kan gevolglik staatmaak op buitelandse kapitaal om hul aktiwiteite te finansier (Ho \& Iyke, 2017). Aan die ander kant redeneer Claessens et al. (2001) dat FDI juis geneig is om na lande met goed gevestigde finansiële stelsels en onderliggende ekonomiese omstandighede te vloei, en dat FDI daardeur aandelemarkontwikkeling komplementeer. Desnieteenstaande behoort FDI plaaslike firmas se deelname in kapitaalmarkte aan te moedig, terwyl dit ook likiditeit in plaaslike markte sal bevorder, en kan sodoende bydra tot die ontwikkeling van die plaaslike aandelemark. Claessens et al. (2001) vind dat daar 'n positiewe korrelasie tussen FDI en aandelemarkkapitalisasie bestaan. Op dieselfde wyse sal die invloei van portefeuljebeleggings plaaslike marklikiditeit bevorder en die finansiering van plaaslike besighede ondersteun.

\footnotetext{
5 Dit sou beteken dat die kapitaal wat nodig is vir plaaslike investering nie deur plaaslike finansiële markte voorsien word nie, maar van die buiteland afkomstig is. Weens knaende lae vlakke van plaaslike besparing, is dit belangrik vir Suid-Afrika om "buitelandse kapitaal te lok ten einde die doelwitte van werkskepping en inklusiewe groei te bereik" (Nasionale Tesourie, 2017:6).
} 
Verder kan internasionale kapitaalvloeie 'n belangrike aanwyser van marksentiment of -risiko wees. Indien daar bv. plaaslike politiese veranderings plaasvind, of 'n algemene risiko-aversie teenoor ontluikende markte bestaan, kan buitelanders hul fondse onttrek, wat weerspieël behoort te word in'n afname in buitelandse aandeelhouding in JSE-maatskappye, 'n kapitaaluitvloei en verswakking in die wisselkoers. Hiermee saam het die agteruitgang in die fiskale posisie (sien bv. Rossouw et al., 2016) en politieke onsekerheid buitelanders se gewilligheid om in sekere lande soos Suid-Afrika te belê, geknou (SARB 2018:66). Verwikkelings in Suid-Afrika sluit bv. in die "Nenegate"skandaal van Desember 2015, waartydens Suid-Afrika drie Finansiesministers binne 'n week gehad het. Feitlik dieselfde storie het homself herhaal in April 2017, toe die Minister van Finansies weereens ontydig vervang is. Dit het o.a. daartoe gelei dat Suid-Afrika se soewereine kredietgradering verlaag is tot spekulatiewe ("junk") status deur twee prominente kredietgraderingsagentskappe (Eyewitness News, 2017a en b; Mail\&Guardian, 2015). Teen hierdie agtergrond is dit duidelik dat internasionale kapitaalvloei, asook die wisselkoers, alhoewel dit hier as "globale" faktore gekategoriseer word, tot 'n groot mate deur plaaslike gebeure beïnvloed kan word. Dit is duidelik dat buitelanders ag slaan op plaaslike nuusgebeure en proaktief hul beleggings hier verminder wanneer negatiewe gebeure gerapporteer word. Dit verskaf dus'n waarskuwing aan Suid-Afrika om sy huis in orde te kry, of om verdere kapitaaluitvloeie (veral sover dit portefeuljevloeie of "hot money" aanbetref) te verwag.

\section{Handelsoopheid}

Handels-liberalisasie kan die vraag na finansiële dienste en produkte verhoog (Svaleryd \& Vlachos, 2002:379), terwyl Rajan \& Zingales (2003) redeneer dat handelsoopheid finansiële aktiwiteite soos investering en banklenings aanmoedig en sodoende die ontwikkeling van finansiële markte bevorder.

Handelsoopheid kan egter ook 'n land blootstel aan eksterne skokke en internasionale mededinging (Svaleryd \&Vlachos, 2002), en kan dus onsekerheid en wisselvalligheid in plaaslike besighede, markte en pryse meebring. Volgens Rajan \& Zingales (2003:21), bring oopheid ook "buitelandse mededingers na plaaslike markte", wat plaaslike winste kan beïnvloed. Terwyl sodanige blootstelling en mededinging plaaslike markte in die langtermyn behoort te versterk, kan dit ook die geval wees dat groot skokke of uiters strawwe mededinging 'n negatiewe invloed op plaaslike markte sou kon hê. Jong of relatief ongevestigde markte en firmas kan veral kwesbaar wees vir groot internasionale skokke. Svaleryd \& Vlachos (2002) en Rajan \& Zingales (2003) vind egter dat handelsoopheid wel oor die algemeen finansiële ontwikkeling aanmoedig.

\section{Finansiële-markliberalisasie}

Volgens Henry (2000: 529) word aandelemarkliberalisasie gesien as 'n "besluit deur' $n$ land se regering om buitelanders toe te laat om aandele in daardie land se aandelemark te koop". Dit laat risiko-deling tussen plaaslike en internasionale beleggers toe, en verlaag dus die koste van kapitaal- en ekwiteitsfinansiering. Liberalisasie verhoog ook deursigtigheid en aanspreeklikheid (Mishkin, 2001), wat korporatiewe bestuur verbeter. 'n Hoër peil van liberalisasie gaan dus gepaard met hoër aandeelpryse, en behoort die ontwikkeling van die plaaslike aandelemark te ondersteun.

\section{Ekonometriese model}

Die eerste stap van die model is om tydreekse aan elkeen van die veranderlikes wat hierbo bespreek is toe te ken. Om 'n ryk datastel te verkry, gebruik ons kwartaallikse waarnemings oor die tydperk 1992 - 2018. Soos vroeër bespreek, is die markkapitalisasie- en omsetkoerse die vernaamste aanduiders van aandelemarkontwikkeling wat in die empiriese literatuur voorkom. Demirgüç-Kunt en Levine (1996) kom tot die gevolgtrekking dat daar 'n positiewe verwantskap tussen markkapitalisasie en ekonomiese ontwikkeling is. Volgens Levine \& Zervos (1998) en Rousseau \& Wachtel (2000) is omset egter 'n meer geskikte maatstaf van aandelemarkontwikkeling, aangesien omset oor die algemeen ' $n$ beter voorspeller as markkapitalisasie van ekonomiese groei is. Daarteenoor redeneer Garcia \& Liu (1999:31) dat markkapitalisasie die meer geskikte aanduider is, aangesien dit "minder arbitrêr as ander individuele maatstawwe...van aandelemarkontwikkeling" is. Desnieteenstaande word markkapitalisasie "gereeld gebruik as 'n aanduider van aandelemarkontwikkeling" (Boyd et al., 2000:229). Indien die semantiese verskil tussen ekonomiese ontwikkeling en ekonomiese groei vir eers opsy geskuif word, is dit duidelik dat beide hierdie twee aanduiders gepaste maatstawwe van aandelemarkontwikkeling kan wees. In hierdie artikel word die markkapitalisasiekoers as afhanklike veranderlike gebruik, vernaam om ons resultate vergelykbaar met verwante SuidAfrikaanse navorsing te hou.

Die markkapitalisasiekoers word bereken deur die verhouding van totale markkapitalisasie op die JSE tot die SuidAfrikaanse BBP. Plaaslike ekonomiese groei is eenvoudig die groeikoers in reële BBP. Banksektorontwikkeling word bepaal deur die verhouding van private kredietverlening tot BBP (Ho \& Odhiambo, 2018). Inflasie word bepaal deur die verandering in die verbruikersprysindeks (VPI), terwyl die prima-uitleenkoers gebruik word as maatstaf van plaaslike rentekoerse. Marklikiditeit kan gemeet word deur die totale waarde of omset ("turnover") van aandele wat op die beurs verhandel (Boyd et al., 2001:229).

Die reële effektiewe wisselkoersindeks (REERI) is 'n meer omvattende maatstaf as 'n enkele wisselkoers ${ }^{6}$ (bv. die

\footnotetext{
6 Die REERI is ‘ $n$ gemiddelde wisselikoers teenoor verskeie internasionale geldeenhede geweeg is. Die REERI is dus ' $n$ beter maatstaf as bilaterale wisselkoerse van ' $n$ land se
} algehele internasionale mededingendheid. 
Rand/Euro-wisselkoers). Internasionale kapitaalvloei kan bepaal word deur die verandering in die saldo van die finansiële rekening van die betalingsbalans (wat die netto invloei van private kapitaal verteenwoordig), of deur die volume van direkte buitelandse investering (FDI) te gebruik. Hier gebruik ons die verhouding van die saldo ${ }^{7}$ op die finansiële rekening van die betalingsbalans tot reële BBP (Yartey, 2010:1620). Handelsoopheid word bepaal deur totale internasionale handel (invoer plus uitvoer) uit te druk as persentasie van reële BBP (Rajan \& Zingales, 2003:27, Svaleryd \& Vlachos, 2002:393).

Die reekse vir sommige van die veranderlikes onder die teoretiese bespreking is egter nie voor die hand liggend nie. Die JSE word gesien as geliberaliseer sedert Desember 1992 (Makina and Negash, 2005:150); dus kan feitlik ons hele steekproef beskou word as "geliberaliseer"8. Die onbeskikbaarheid van 'n lang genoeg tydreeks verhoed ons verder om korporatiewe bestuur as verklarende veranderlike in 'n ekonometriese model in te sluit'. Die faktore wat in ons model ingesluit word kan dus soos volg opgesom word:

\section{Metodologie en empiriese toetse}

Om die impak van hierdie faktore op Suid-Afrikaanse aandelemarkontwikkeling te toets, volg ons Pesaran \& Shin (1999) en Pesaran, Shin \& Smith (2001, hierna PSS) se "autoregressive distributed lag" (ARDL) grenstoets ("bounds testing")-prosedure. Die voordele van hierdie benadering is sy krag in relatief kort tydreekse, en die feit dat hierdie benadering ook toegepas kan word op 'n model wat tydreekse met verskillende ordes van integrasie bevat. Die tegniek word eers teoreties geillustreer, waarna die omvattende model in 'n volgende afdeling geraam word.

\section{Stap 1: Kö̈ntegrasie}

Die eerste stap van die ARDL-prosedure is om die nulhipotese dat daar geen koïntegrerende verhouding tussen die veranderlikes is nie

$$
H_{0}: \theta_{1}=\theta_{2}=\cdots=\theta_{j}=0
$$

te toets teenoor die alternatiewe hipotese dat daar wel 'n koïntegrerende verhouding tussen die veranderlikes bestaan

$$
H_{1}: \theta_{1} \neq \theta_{2} \neq \cdots \neq \theta_{j} \neq 0
$$

aan die hand van die volgende uitdrukking:

$$
\begin{gathered}
\Delta Y_{t}=\beta+\sum_{i=1}^{n} \beta_{0 i} \Delta Y_{t-i} \sum_{i=1}^{n} \beta_{1 i} \Delta X_{1, t-i}+\sum_{i=1}^{n} \beta_{2 i} \Delta X_{2, t-i}+\cdots+\sum_{i=1}^{n} \beta_{j i} \Delta X_{j, t-i} \\
+\theta_{1} X_{1, t-i}+\theta_{2} X_{2, t-1}+\cdots+\theta_{j} X_{j, t-1}+\varepsilon_{t}
\end{gathered}
$$

$Y_{t}$ is die afhanklike veranderlike, en $X=\left(X_{1}, X_{2}, \ldots, X_{j}\right)$ verteenwoordig ' $n$ versameling verklarende veranderlikes. $\beta_{j i}$ en $\theta_{j i}$ verteenwoordig die veranderlikes se kort- en langtermyn-koeffisiënte onderskeidelik. $\Delta$ is die verskil tussen opeenvolgende waarnemings in die data (die "first difference operator"), en $\varepsilon_{t}$ is die stogastiese foutterm ("residual term"). Koïntegrasie móét teenwoordig wees (m.a.w. die langtermynkoeffisiënte moet gesamentlik statisties beduidend wees) om te verseker dat die model betroubaar geskat kan word. Die optimale sloering ("lag") (i) van elke veranderlike (insluitende die afhanklike veranderlike) word bepaal deur die sloeringslengtes te simuleer, en dan die lengtes te kies wat die minimum Schwarz inligtingskriteria (SIC) oplewer.

Die koïntegrasie-hipotese word getoets deur van 'n F-toets gebruik te maak, waar die model se berekende $F$-statistiek vergelyk word teen die PSS kritieke waardes. Die PSS kritieke waardes - vir 'n gegewe vertrouensinterval en

\begin{tabular}{|c|c|c|c|c|}
\hline & Veranderlike: & Invloed: & Tydreeks/aanwyser: & Bron: \\
\hline & Aandelemarkontwikkeling $(M C R)$ & & JSE markkapitalisasie / BBP & Eie berekeninge, SARB \\
\hline \multirow{4}{*}{$\begin{array}{l}\frac{0}{\pi} \\
\stackrel{0}{0} \\
\frac{0}{0} \\
\frac{t}{\pi} \\
\frac{\pi}{2}\end{array}$} & Plaaslike ekonomiese groei (RGDPG) & + & Reële BBP groei & SARB \\
\hline & $\begin{array}{l}\text { Plaaslike finansiële (banksektor) } \\
\text { ontwikkeling (BNK) }\end{array}$ & $+/-$ & Private krediet-verlening / BBP & Eie berekeninge, SARB \\
\hline & Inflasie (INF) & - & Verandering in die VPI-indeks & Eie berekeninge, StatsSA \\
\hline & Marklikiditeit (TOR) & + & $\begin{array}{l}\text { Omset ("turnover") van aandele } \\
\text { verhandel op die JSE }\end{array}$ & SARB \\
\hline \multirow{5}{*}{$\begin{array}{l}\frac{0}{\pi} \\
\frac{0}{2} \\
\frac{0}{0} \\
\frac{t}{\varpi}\end{array}$} & Rentekoerse (PRIME) & $+/-$ & Prima uitleenkoers & IMF IFS \\
\hline & Wisselkoers (REERI) & $+/-$ & Reële effektiewe wisselkoers & IMF IFS \\
\hline & Internasionale kapitaalvloei (FLOWR) & + & $\frac{\text { Balans op die finansiële rekening }}{\text { Reële BBP }}$ & SARB \\
\hline & \multirow[t]{2}{*}{ Handelsoopheid (OPEN) } & \multirow[t]{2}{*}{+} & Invoer + Uitvoer & \multirow{2}{*}{ Eie berekeninge, SARB } \\
\hline & & & Reële BBP & \\
\hline
\end{tabular}
steekproefgrootte - val binne 'n bepaalde gebied, met 'n duidelike onderste en boonste grens (vanwaar die

TABEL 1: Veranderlikes en aanwysers

Bronne: Die Internasionale Monetêre Fonds (IMF) se International Financial Statistics (IFS), Statistiek Suid-Afrika (StatsSA) en die Suid-Afrikaanse Reserwebank (SARB) se aanlyn-databasis gebaseer op die kwartaalblad.

7 'n Positiewe saldo verteenwoordig 'n netto kapitaalinvloei.

8 Weens die internasionale sanksies teen Suid-Afrika gedurende die 1980s is ons versigtig om ons steekproef té ver in die verlede uit te brei.

9 Die Institute of Internal Auditors SA stel sedert slegs 2013 'n Corporate Governance Index vry. Die berekening van alternatiewe maatstawwe van korporatiewe bestuur val egter buite die bestek van hierdie navorsing. 
"bounds"-benaming van die toets). Indien die F-statistiek kleiner is as die onderste PSS grens kan die nul-hipotese (geen koïntegrasie) nie verwerp word nie. Indien die F-statistiek die boonste PSS grens oorskry kan ons die nulhipotese verwerp en aanvaar dat daar wel koïntegrasie tussen die veranderlikes bestaan. Indien die F-statistiek tussen die twee grense val is die toets onbeslis.

Stap 2: ECM ("error-correction model")

Indien 'n koïntegrerende verhouding tussen die veranderlikes wel teoreties vasgestel kan word, is die volgende stap om 'n korttermyn fout-korreksie model ("errorcorrection"-model (ECM) te skat, wat soos volg voorgestel word:

$$
\begin{gathered}
\Delta Y_{t}=\beta+\sum_{i=1}^{n} \beta_{0} \Delta Y_{t-i}+\sum_{i=1}^{n} \beta_{1 i} \Delta X_{1, t-i}+\sum_{i=1}^{n} \beta_{2 i} \Delta X_{2, t-i}+\cdots+\sum_{i=1}^{n} \beta_{j i} \Delta X_{j, t-i} \\
+\delta E C M_{t-1}+\mu_{t}
\end{gathered}
$$

om die model se dinamika rondom die langtermyntendens voor te stel. Die ECM-term is eenvoudig die foutterm van die langtermynskatting hierbo $\left(\varepsilon_{t}\right)$, en verteenwoordig die "terugkeer" van die verduidelikende veranderlikes na die langtermynewewig. Die koeffisiënt behoort negatief te wees, terwyl $|\delta|<1$ op 'n stabiele terugkeer na die ewewig dui.

\section{Stasionariteit}

Al die veranderlikes word getoets vir stasionariteit ("stationarity") deur van die "Augmented Dickey-Fuller" (ADF)-toets gebruik te maak. Aangesien die meerderheid makro-ekonomiese tydreekse oor tyd styg, verwag ons dat sulke veranderlikes 'n duidelike eenheidswortel ("unit

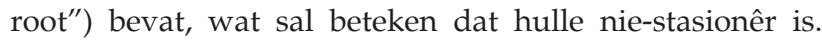
Indien veranderlikes nie-stasionêr is, verloor die gewone kleinste-kwadrate ("ordinary least squares", OLS) modelleringstegniek sy effektiwiteit en vermoë om akkurate gevolgtrekkings te maak. Veranderlikes soos rentekoerse, inflasie, en reekse wat as verhoudings uitgedruk word (bv. krediet:BBP) kan egter netsowel stasionêr of nie-stasionêr wees. Ons verwag dus 'n kombinasie van I(0)- (stasionêre) en I(1)- (nie-stasionêre) veranderlikes. Dit is presies in so 'n omgewing waar die PSS-prosedure goeie resultate lewer. Tabel 2 hieronder toon die resultate van die ADF-toetse en

TABEL 2: Stasionariteit

\begin{tabular}{l|c|c|c}
\hline Veranderlike: & ADF-statistiek & Kritiese waarde & Integrasie-orde \\
\hline In_MCR & -8.538 & -3.495 & $\mathrm{I}(1)$ \\
$R G D P G$ & -5.350 & -3.494 & $\mathrm{I}(0)$ \\
In_BNK & -2.314 & -1.944 & $\mathrm{I}(1) * *$ \\
In_INF & -5.055 & -3.494 & $\mathrm{I}(0)$ \\
In_TOR & -4.588 & -3.500 & $\mathrm{I}(1)$ \\
In_PRIME & -5.996 & -3.494 & $\mathrm{I}(1)$ \\
In_REERI & -8.514 & -3.494 & $\mathrm{I}(1)$ \\
FLOWR & -11.659 & -3.496 & $\mathrm{I}(1)$ \\
In_OPEN & -11.131 & -3.496 & $\mathrm{I}(1)$ \\
\hline
\end{tabular}

${ }^{+}$Sonder afsnit of tendens. Statisties beduidend by die $5 \%$-vertrouensinterval. Alle ander toetse is statisties beduidend by die $1 \%$-vertrouensinterval. Bron: Eie berekeninge. die integrasie-orde van elke veranderlike. Die resultate bevestig dat ons model 'n kombinasie van stasionêre en nie-stasionêre veranderlikes insluit, en ondersteun dus ons keuse van die PSS-prosedure verder. Ons gebruik die natuurlike logaritmes van elke veranderlike, behalwe RGDPG en FLOWR (wat negatiewe waardes bevat).

\section{Omvattende model}

Ons omvattende ekonometriese model brei die eenvoudige model van Ho (2018), geraam op die Suid-Afrikaanse ekonomie uit deur addisionele veranderlikes in te sluit. Die model word geskat deur van BNK, INF, RGDPG, TOR, PRIME, OPEN, REERI en FLOWR as verduidelikende veranderlikes gebruik te maak, met $M C R$ die afhanklike veranderlike (sien Tabel 1). Die model word dus voorgestel deur

$$
\begin{aligned}
\triangle M C R_{t}=\beta & +\sum_{i=1}^{n} \beta_{0 i} \Delta M C R_{t-i} \sum_{i=1}^{n} \beta_{1 i} \Delta B N K_{t-i}+\sum_{i=1}^{n} \beta_{2 i} \Delta \mathrm{INF}_{t-i}+\sum_{i=1}^{n} \beta_{3 i} \Delta \mathrm{RGDPG}_{t-i} \\
& +\sum_{i=1}^{n} \beta_{4 i} \Delta \mathrm{TOR}_{t-i}+\sum_{i=1}^{n} \beta_{5 i} \Delta \mathrm{PRIME}_{t-i}+\sum_{i=1}^{n} \beta_{6 i} \Delta \mathrm{OPEN}_{t-i} \\
& +\sum_{i=1}^{n} \beta_{7 i} \Delta \mathrm{REERI}_{t-i}+\sum_{i=1}^{n} \beta_{8 i} \Delta \mathrm{FLOWR}_{t-i}+\theta_{1} B N K_{1, t-i}+\theta_{2} \mathrm{INF}_{t-1} \\
& +\theta_{3} \mathrm{RGDPG}_{t-1}+\theta_{4} \mathrm{TOR}_{t-1}+\theta_{5} \mathrm{PRIME}_{t-1}+\theta_{6} \mathrm{OPEN}_{t-1}+\theta_{7} \mathrm{REERI}_{t-1} \\
& +\theta_{8} \mathrm{FLOWR}_{t-1}+\varepsilon_{t}
\end{aligned}
$$

\begin{tabular}{|c|c|c|c|c|}
\hline Toetsstatistiek & Waarde & Beduidendheid & $I(0)$ & I(1) \\
\hline F-statistiek & $\begin{array}{c}4.84880 \\
2 \\
\end{array}$ & $10 \%$ & 1.85 & 2.85 \\
\hline$k$ & 8 & $5 \%$ & 2.11 & 3.15 \\
\hline & & $2.5 \%$ & 2.33 & 3.42 \\
\hline & & $1 \%$ & 2.62 & 3.77 \\
\hline
\end{tabular}

Die berekende F-statistiek is groter as die PSS kritieke waardes vir alle vertrouensvlakke (Tabel 3). Ons kan dus met sekerheid die nul-hipotese verwerp en aanvaar dat daar wel koïntegrasie tussen die veranderlikes bestaan, en daarom voortgaan om die model te beraam.

TABEL 3: ARDL grenstoets

Bron: Pesaran, Shin \& Smith (2001:300), Tabel Cl(ii).

Die volgende stap is om die optimale sloerings te bepaal. Die minimum SIC stel 'n ARDL(1,0,0,0,1,0,0,0,0)-model vas. Die syfers tussen hakies verteenwoordig die hoeveelheid sloerings per veranderlike wat in die model ingesluit word, met eersgenoemde m.b.t. die afhanklike veranderlike $(M C R)$ en die laaste agt m.b.t. die agt verskillende verduidelikende veranderlikes. Slegs een sloering van die omsetkoers (TOR) word dus ingesluit. Die lang- en korttermynresultate word in Tabel 4 gerapporteer. Die model slaag al die diagnostiese toetse ${ }^{10}$. 
TABEL 4: Resultate

\begin{tabular}{|c|c|c|c|c|}
\hline & Koeffisiënt & Std.f out & t-statistiek & $p$-waarde \\
\hline \multicolumn{5}{|l|}{ Langtermyn } \\
\hline LN_BNK & 4.397066 & 2.365210 & 1.859060 & $0.0662^{*}$ \\
\hline LN_INF & -0.072064 & 0.194550 & -0.370415 & 0.7119 \\
\hline RGDPG & 0.119016 & 0.062730 & 1.897282 & 0.0609* \\
\hline LN_TOR & -0.298021 & 0.277213 & -1.075059 & 0.2851 \\
\hline LN_PRIME & -1.812503 & 0.859677 & -2.108354 & $0.0377^{* *}$ \\
\hline LN_OPEN & -4.367704 & 2.304421 & -1.895359 & $0.0612^{*}$ \\
\hline LN_REERI & -2.526386 & 1.500665 & -1.683511 & $0.0956 *$ \\
\hline FLOWR & 3.624344 & 2.997309 & 1.209199 & 0.2297 \\
\hline$\beta$ & 14.46847 & 8.467977 & 1.708610 & 0.0909* \\
\hline \multicolumn{5}{|l|}{ Korttermyn } \\
\hline $\mathrm{D}\left(\mathrm{LN} \_\mathrm{TOR}\right)$ & 0.072161 & 0.024366 & 2.961610 & $0.0039 * * *$ \\
\hline ECM(-1) & -0.085085 & 0.011667 & -7.292490 & $0.0000 * * *$ \\
\hline
\end{tabular}

Bron: Eie berekeninge. $* * *, * *$ en $*$ dui op statistiese betekenisvolheid van onderskeidelik, $1 \%$, $5 \%$ en $10 \%$.

\section{Bespreking van die resultate Langtermyn}

Die langtermynresultate toon dat banksektorontwikkeling, ekonomiese groei, handelsoopheid en die wisselkoers statisties beduidend is teen $10 \%$, en dat die rentekoers statisties beduidend is teen $5 \%$. Dit sou wenslik wees om die koëffisiënte met sterker vertroue te kon interpreteer, maar verskeie van die bronne wat vir hierdie artikel geraadpleeg is, lewer egter resultate op wat ook net teen $10 \%$ statisties betekenisvol is (sien o.a. Rousseau \& Wachtel, 2000 en Claessens et al., 2001). In hierdie lig behou ons ons dus daarby om slegs die rigting en betekenisvolheid van die koëffisiënte te bespreek, sonder om verdere afleidings oor die elastisiteite of voorspellingsvermoë van die model te maak.

Plaaslike aandrywers van Suid-Afrikaanse aandelemarkontwikkeling sluit dus ekonomiese groei, banksektorontwikkeling, en plaaslike rentekoerse in, terwyl globale faktore die wisselkoers en handelsoopheid insluit. Inflasie, marklikiditeit en kapitaalvloei speel nie 'n rol in die langtermyn nie. Soos die teorie voorspel, het plaaslike ekonomiese groei 'n duidelike positiewe impak op aandelemarkontwikkeling. Banksektorontwikkeling komplementeer aandelemarkontwikkeling, wat Levine (2005) se argument staaf. Die negatiewe koeffisiënt van die rentekoers ondersteun ook die teorie dat hoër finansieringskoste aandelemarkontwikkeling belemmer. Hierdie bevindinge strook met Ho (2018) se resultate van die Suid-Afrikaanse ekonomie, asook die breë empiriese literatuur.

Die negatiewe verwantskap tussen die wisselkoers en aandelemarkontwikkeling dui daarop dat soos wat die rand depresieer, ontwikkel die aandelemark. Die swakker geldeenheid kan dus buitelandse kapitaal lok wat na die aandelemark toe vloei, wat konsekwent is met Dornbusch \& Fischer (1980) se teorie. Verder verhoog die swakker rand plaaslike mededingendheid op die internasionale front, en daardeur verhoog plaaslike produksie, aandelemarkontwikkeling, en aandeelpryse. 'n Interessante resultaat is dat handelsoopheid 'n negatiewe impak op aandelemarkontwikkeling het. Dit bots met die internasionale bevindinge, maar is konsekwent met Ho (2018) se vergelykbare studie op die Suid-Afrikaanse ekonomie. Een moontlike rede is dat ' $n$ beduidende deel van JSE-genoteerde maatskappye se verdienste in werklikheid in die buiteland verdien word. By raming is sowat 62 persent van die JSE Top 40-maatskappye se verdienste in 2017 in die buiteland gegenereer (Sharenet, 2017). Alternatiewelik, en soos reeds aangedui in afdeling 2.2.3, kan jong of relatief ongevestigde markte en firmas kwesbaar wees teen groot internasionale skokke. Sodanige groot skokke, of die internasionale kompetisie wat uit handelsoopheid voortspruit, kan dus 'n negatiewe invloed op plaaslike markte uitoefen. Dit blyk dat dit wel die geval is in die Suid-Afrikaanse konteks.

Die resultate dat inflasie, marklikiditeit en kapitaalvloei nie statisties betekenisvol is nie is onverwags, maar kom ook soms in die literatuur voor. Ho (2018) bespeur 'n negatiewe en betekenisvolle verwantskap tussen inflasie en die markkapitalisasiekoers. Boyd et al. (2001) en Yartey (2010) bespeur egter ook nie 'n statistiese betekenisvolle verwantskap tussen inflasie en markkapitalisasie nie. Claessens et al. (2001) en Yartey (2010) vind 'n positiewe en betekenisvolle verwantskap tussen kapitaalinvloeie en die markkapitalisasiekoers oor 'n steekproef van ontluikende ekonomieë. Portefeuljebeleggings is egter nie beperk tot aandeleverhandeling nie, en kapitaalvloei kan dus op verskillende maniere plaasvind wat nie almal direk verband hou met aandelemarkkapitalisasie nie. In die SuidAfrikaanse konteks kan kapitaaluitvloeie bv. in die vorm van die verkoop van valuta manifesteer, wat 'n beperkte direkte impak op markkapitalisasie sal hê. Sodanige kapitaaluitvloei sal natuurlik bydra tot ' $n$ depresiasie in die rand, wat mettertyd tot 'n toename in markkapitalisasie behoort te lei, soos hierbo bespreek. Kapitaalvloeie en die wisselkoers kan mekaar dus wedersyds beïnvloed, en die kontrolerende effek van die wisselkoers verminder daarom vermoedelik die rol en betekenisvolheid van kapitaalvloei in die ekonometriese model. Laastens bespeur Ho \& Odhiambo (2018) ook 'n statisties-onbeduidende verwantskap tussen hul maatstaf van marklikiditeit (die omsetkoers) en markkapitalisasie, maar dit is in teenstelling met die resultate van Garcia \& Liu (1999). Die verband tussen markkapitalisasie en marklikiditeit word dus geoormerk vir toekomstige navorsing.

\section{Korttermyn}

Die enigste veranderlike wat 'n statisties-beduidende impak in die korttermyn gehad het, was marklikiditeit. 'n Meer likiede mark veroorsaak dat daar meer transaksies op die beurs plaasvind, wat uiteraard die beurs se ontwikkeling ondersteun. Die koeffisiënt van die ECM-term is negatief, statisties beduidend en val tussen - 1 en 0 . Dit is na wense, en dui daarop dat die model stabiel is rondom die langtermyn-ewewig. 


\section{Kousaliteit}

In die inleiding en literatuuroorsig is die positiewe impak van aandelemarkontwikkeling op ekonomiese groei en ontwikkeling kortliks bespreek. Volgens Garcia \& Liu (1999:35) speel finansiële ontwikkeling, bv. ontwikkeling van die aandelemark, 'n belangrike rol in ekonomiese groei, maar kan ekonomiese groei netsowel finansiële ontwikkeling aanmoedig. Deur middel van 'n Grangerkousaliteitstoets word die kousaliteit tussen aandelemarkontwikkeling (soos gemeet deur die markkapitalisasiekoers) en ekonomiese groei dus ondersoek.

Volgens Paneel (a) van Tabel 5 kan ons die hipotese dat ekonomiese groei nie aandelemarkontwikkeling veroorsaak nie, nie verwerp nie. Die hipotese dat aandelemarkontwikkeling nie ekonomiese groei veroorsaak nie, word wel verwerp. Daar is verder geen bewys dat daar tweerigting-kousaliteit tussen ekonomiese groei en aandelemarkomset bestaan nie (Paneel (b) van Tabel 5).

TABEL 5: Granger-kousaliteit

\begin{tabular}{l|c|c}
\hline & F-statistiek & $p$-waarde \\
\hline (a) Ekonomiese groei en markkapitalisasie & & \\
\hline RGDPG does not Granger Cause LN_MCR & 0.56294 & 0.8051 \\
\hline LN_MCR does not Granger Cause RGDPG & 3.56210 & 0.0014 \\
\hline (b) Ekonomiese groei en omset & & \\
\hline LN_TOR does not Granger Cause RGDPG & 1.11825 & 0.3528 \\
\hline RGDPG does not Granger Cause LN_TOR & 1.46150 & 0.2203 \\
\hline
\end{tabular}

Bron: Eie berekeninge.

Die gevolgtrekking is dat daar wel omgekeerde kousaliteit tussen die markkapitalisasiekoers en ekonomiese groei bestaan, wat beteken dat die JSE ' $n$ betekenisvolle rol in plaaslike ekonomiese groei speel. Alhoewel dit teenstrydig met sommige ander resultate is ${ }^{11}$, is dit nie verassend nie, aangesien die finansiële sektor ' $n$ baie groot gedeelte van die Suid-Afrikaanse ekonomie beslaan. Dit dui egter daarop dat die Suid-Afrikaanse ekonomie uniek is - in teenstelling met ander ekonomieë - in hoe belangrik die plaaslike aandelemark vir algehele ekonomiese groei is. Dit is ' $n$ interessante resultaat wat ons oormerk vir toekomstige navorsing.

\section{Gevolgtrekkings}

Hierdie navorsing poog om 'n aantal ekonomiese faktore wat verantwoordelik mag wees vir die ontwikkeling van die plaaslike aandelemark te ondersoek, en om te bepaal of hierdie faktore ' $n$ internasionale of plaaslike oorspong het. Aan die hand van die internasionale literatuur en empiriese studies is verskeie faktore wat aandelemarkontwikkeling behoort te beïnvloed, geïdentifiseer en breedvoerig bespreek. Pesaran \& Shin (1999) en Pesaran, Shin \& Smith (2001) se "autoregressive distributed lag" (ARDL) grens- toets ("bounds testing")-prosedure is aangewend om die invloed van hierdie faktore op die JSE se markkapitalisasiekoers, die aanwyser vir aandelemarkontwikkeling, te toets.

Dit is duidelik dat globale én nasionale faktore die ontwikkeling van die JSE beïnvloed. Sowel die wisselkoers as handelsoopheid het 'n negatiewe verwantskap met aandelemarkontwikkeling. ' $n$ Swakker rand dra by tot meer ontwikkeling van die JSE, terwyl meer handelsoopheid JSE-ontwikkeling belemmer. Plaaslike ekonomiese groei en banksektorontwikkeling bevorder die ontwikkeling van die JSE, terwyl plaaslike rentekoerse 'n negatiewe verwantskap met aandelemarkontwikkeling toon. Verder is daar getuienis dat aandelemarkontwikkeling weer 'n betekenisvolle rol in ekonomiese groei speel. Aan die hand van hierdie resultate is dit egter baie moeilik om die belangrikheid van plaaslike en internasionale faktore teen mekaar op te weeg. ' $n$ Verdere penarie is die interafhanklikheid van baie van hierdie faktore. Soos hierbo bespreek, kan "nasionale" gebeure heel moontlik "globale" veranderlikes beïnvloed, bv. kapitaaluitvloei en wisselkoersskommelinge a.g.v. plaaslike politieke struwelinge en beleidsonsekerheid. Die wisselkoers beïnvloed weer op sy beurt plaaslike ekonomiese groei en inflasie, terwyl ekonomiese groei en aandelemarkontwikkeling mekaar wedersyds beïnvloed. Daar is dus voortdurend 'n spanning tussen globale en nasionale faktore, en hul wedersydse invloed op die JSE.

Sover moontlik behoort plaaslike aandrywers van aandelemarkontwikkeling, naamlik ekonomiese groei en die banksektor, egter gekoester te word om 'n gesonde aandelemark te ondersteun en sodoende ekonomiese ontwikkeling aan te moedig. Terselftertyd is dit belangrik dat kennis gedra word van hoe plaaslike gebeure internasionale faktore soos wisselkoerse kan beïnvloed, en hoe dit die JSE behoort te raak.

\section{Erkennings}

Ons erken graag Dr Sin-Yu Ho, van die Departement Ekonomie aan Unisa, se insette in hierdie navorsing.

\section{Verwysings}

Biznews. 2016. SA grants first stock exchange licence in 100yrs - ZARX to compete with JSE, 30 Maart 2016. [Aanlyn - 19 Februarie 2019] https://www.biznews. com/briefs/2016/03/30/sa-grants-first-stock-exchange-licence-100yrszarxcompete-jse/

Boyd JH, Smith BD. 1998. Capital market imperfections in a monetary growth model. Economic Theory 11, 241-273.

Boyd JH, Levine R, Smith BD. 2001. The impact of inflation on financial market performance. Journal of Monetary Economics 47(2001), 221-248.

Claessens S, Rhee MW. 1993 The effect of equity barriers on foreign investment in developing countries. NBER Working Paper Series No. 4579.

\footnotetext{
11 Sien bv. Levine \& Zervos (1998) en Rousseau \& Wachtel (2000), wat vind dat markkapitalisasie nie ' $n$ sterk voorspeller van ekonomiese groei is nie, maar dat daar wel kousaliteit van aandelemarkomset na ekonomiese groei is. Hul resultate is egter afgelei van paneel-studies oor ' $n$ breë steekproef van ekonomieë, wat die ervaring van individuele ekonomieë verlore kan laat gaan.
} 
Claessens S, Klingebiel D, Schmukler SL. 2001. FDI and stock market development: Complements or substitutes?. Washington: World Bank.

Demirgüç-Kunt A, Levine R. 1996. Stock Market Development and Financial Intermediaries: Stylized Facts. The World Bank Economic Review 10(2), 291 321.

Dornbusch R, Fischer S. 1980. Exchange rates and the current account. American Economic Review 70(5), 960-971.

Eyewitness News. 2017a. Analyst: New Finance Minister Malusi Gigaba will have to learn quickly, 31 Maart 2017. [Aanlyn - 19 Februarie 2019] hк p:// ewn.co.za/2017/03/31/analyst-new-fi nance-minister-gigaba-will-have-toewn.co.za/2017

Eyewitness News. 2017b. Fitch downgrades South Africa to junk status, 7 April 2017 [Aanlyn - 19 Februarie 2019] http://ewn.co.za/2017/04/07/breakingfitchdowngrades-south-africa-to-junk-status

Garcia VF, Liu L. 1999. Macroeconomic determinants of stock market development. Journal of Applied Economics 2, 29-59.

Gavin M. 1989. The stock market and exchange rate dynamics. Journal of International Money and Finance 8, 181-200.

Greenwood J, Smith B. 1997. Financial markets in development, and the development of financial markets. Journal of Economic Dynamics and Control 21(1), 145-181.

Henry PB. 2000. Stock market liberalization, economic reforms and emerging market equity prices. Journal of Finance 58(2), 529-563.

Ho S-Y. 2018. Macroeconomic Determinants of Stock Market Development in South Africa. International Journal of Emerging Markets, https://doi.org/10.1108/ IJoEM-09-2017-0341.

Ho S-Y, lyke BN. 2017. Determinants of stock market development: a review of the literature. Studies in Economics and Finance 34(1), 143-164.

Ho S-Y, Odhiambo NM. 2018. Analysing the macroeconomic drivers of stock market development in the Philippines. Cogent Economics and Finance 6(1), 143-164.

Johannesburg Stock Exchange (JSE), 2017a. [Aanlyn - 19 Februarie 2019]. https:// www.jse.co.za/

Johannesburg Stock Exchange (JSE), 2017b. [Aanlyn - 19 Februarie 2019] https:// www.jse.co.za/services/market-data/indices/ftse-jse-africa-index-series/ headline.

Levine R, Zervos S. 1998. Stock Markets, Banks, and Economic Growth. American Economic Review 88(3), 537-558.

Levine R. 2005. Finance and growth: theory and evidence, in Aghion, P. and Durlauf, S. (red.), Handbook of Economic Growth, vol. 1, 1ste uitgawe, Elsevier.

Mail\&Guardian. 2015. Zuma appoints Pravin Gordhan as finance minister, 13 December 2015. [Aanlyn - 19 Februarie 2019] https://mg.co.za/article/201512-13-zuma-appoints-pravin-gordhan-as-finance-minister

Makina D, Negash, M. 2005. Stock Market Liberalization and the Cost of Equity Capital: Evidence from Johannesburg Stock Exchange (JSE) Listed Firms. Journal of Accounting and Finance Research 14(4), 145-167.

Mishkin FS. 2001. Financial policies and the prevention of financial crises in emerging market countries. NBER Working Paper No. 8087, NBER, Cambridge.
Mishkin FS. 2013. The Economics of Money, Banking and Financial Markets, 10e uitgawe, Pearson Education Limited.

Mok HMK. 1993. Causality of interest rate, exchange rate and stock prices at stock market open and close in Hong Kong. Asia Pacific Journal of Management 10(2), 123-143.

Nasionale Tesourie. 2017. Ownership of JSE-listed companies. Research Report for

National Treasury, September 2017. [Aanlyn - 19 Februarie 2019] http://www. treasury.gov.za/comm media/press/2017/2017100301\%200wnership\%20 monitor\%20-\%20Sept\%202017.pdf

Pesaran MH, Shin Y. 1999. An autoregressive distributed lag modelling approach to cointegration analysis. In: Econometrics and Economic Theory in the 20th Century: The Ragnar Frisch Centennial Symposium (red. Steinar Strøm), Cambridge: Cambridge University Press, Hoofstuk 11, 371-413.

Pesaran MH, Shin Y, Smith RJ. 2001. Bounds testing approaches to the analysis of level relationships. Journal of Applied Econometrics, 16(3), 289-326.

Rajan R, Zingales L. 2003. The great reversals: The politics of financial development in the twentieth century. Journal of Financial Economics 69(2003), 5-50.

Rousseau PL, Wachtel P. 2000. Equity markets and growth: Cross-country evidence on timing and outcomes, 1980-1995. Journal of Banking and Finance 24(2000) 1933-1957.

Rossouw J, Joubert F, Breytenbach A. 2016. Suid-Afrika se fi skale keuses gemodeleer: Afgrond of plato? Tydskrif vir Geesteswetenskappe, 56(2-2), 534 554

SA Shares. 2018. [Aanlyn - 19 Februarie 2019] https://www.sashares.co.za/ jsetop-40/

Sharenet. 2017. SA Top 40 off shore exposure revealed. 31 Maart 2017. [Aanlyn - 19 Februarie 2019] hк p://www.sharenet.co.za/views/SA-TOP40-Off shoreExposure-Revealed/6da26db0ba616877a456cd59bdde4789

South African History Online (SAHO). 2017. The Johannesburg Stock Exchange is established, 7 November 2017. [Aanlyn - 19 Februarie 2019] http://www. sahistory.org.za/dated-event/johannesburg-stock-exchange-established

Suid-Afrikaanse Reserwebank (SARB), 2018. Kwartaalblad, Maart 2018.

Svaleryd H, Vlachos J. 2002. Markets for risk and openness to trade: How are they related? Journal of International Economics 57(2002), 369-395.

UNCTAD (The United Nations Conference on Trade and Development), 2017 The role of stock exchanges in fostering economic growth and sustainable development. [Aanlyn - 19 Februarie 2019] https://unctad.org/en/pages/ PublicationWebfler.aspx?publicationid $=1866$

World Federation of Exchanges (WFE). 2018. Monthly report: January 2018. [Aanlyn - 19 Februarie 2019] https://www.world-exchanges.org/home/index. $\mathrm{php} /$ statistics/monthly-reports

Yartey CA. 2007. Well-developed financial intermediary sector promotes stock market development: evidence from Africa. Journal of Emerging Market Finance 6(3), 269-289.

Yartey CA, 2010. The institutional and macroeconomic determinants of stock market development in emerging economies. Applied Financial Economics 20(21), 1615-1625. 


\section{Bylaag A: Diagnostiese toetse}

Die model slaag al die diagnostiese toetse. Die Jarque-Beratoets dui daarop dat die foutterme normaal verdeel is, terwyl die White-toets homoskedastisiteit in die foutterme aandui. Die Breusch-Godfrey-LM-toets bespeur geen

TABEL A.1: Diagnostiese toetse

\begin{tabular}{l|c|c}
\hline Toets & Statistiek & $\boldsymbol{p}$-waarde \\
\hline Normaliteit (Jarque-Bera-toets) & 0.485 & 0.785 \\
\hline Heteroskedastisiteit (White-toets) & 1.470 & 0.101 \\
\hline Outokorrelasie (Breusch-Godfrey LM-toets) & 1.412 & 0.203 \\
\hline
\end{tabular}

Bron: Eie berekeninge.

\section{Figuur A.1: CUSUM- en CUSUMSQ-toetse}

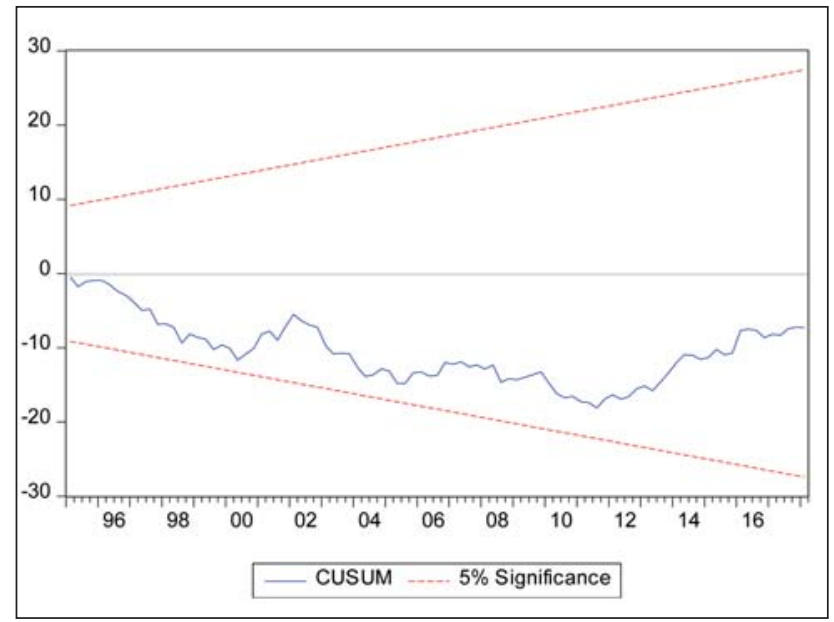

outokorrelasie met 'n sloering van 8 kwartale nie. Laastens toon die CUSUM- en CUSUMSQ-toetse 'n stabiele model aan (Figuur A.1). 